University of Nebraska - Lincoln

DigitalCommons@University of Nebraska - Lincoln

Faculty Publications, Department of Child, Youth, and Family Studies

Child, Youth, and Family Studies, Department of

2021

Doing Assessment: A Multicase Study of Preschool Teachers'

Language and Literacy Data Practices

Rachel E. Schachter

Shayne B. Piasta

Follow this and additional works at: https://digitalcommons.unl.edu/famconfacpub

Part of the Developmental Psychology Commons, Family, Life Course, and Society Commons, Other Psychology Commons, and the Other Sociology Commons

This Article is brought to you for free and open access by the Child, Youth, and Family Studies, Department of at DigitalCommons@University of Nebraska - Lincoln. It has been accepted for inclusion in Faculty Publications, Department of Child, Youth, and Family Studies by an authorized administrator of DigitalCommons@University of Nebraska - Lincoln. 


\title{
Doing Assessment: A Multicase Study of Preschool Teachers' Language and Literacy Data Practices
}

\author{
Rachel E. Schachter University of Nebraska-Lincoln \\ Shayne B. Piasta The Ohio State University
}

\begin{abstract}
Early childhood research and policy have promoted the use of language and literacy assessment data to inform instruction. Yet, there is a limited understanding of preschool teachers' data practices and sensemaking, particularly when considered from the perspectives of practicing teachers. In this multicase study, we used a phenomenological approach to generate a theory about preschool teachers' data practices in relation to supporting children's language and literacy outcomes. Twenty preschool teachers participated in a series of three observations, planning interviews, and stimulated recall interviews designed to tap their pedagogical reasoning and data use practices. The framework that emerged through iterative within-and crosscase analyses comprised three major elements (what teachers knew, how they knew it, and the way they used the data) and suggested that teachers could be characterized into three data use profiles (data gatherers, in-themoment data users, and integrated data users). Findings indicate (a) teachers may understand data differently than researchers or policymakers do, (b) teachers' understanding of data sources goes beyond traditional conceptualizations, (c) a continuum in teachers' data use practices, and (d) a need to better support teachers in moving from simply doing assessment to using data in ways that are meaningful for practice and children's language and literacy outcomes.
\end{abstract}

Published in Reading Research Quarterly (2021), 21 pp.

doi:10.1002/rrq.419

Copyright (C) 2021 International Literacy Association. Published by John Wiley \& Sons Co. Used by permission.

Submitted September 21, 2020; revised April 2, 2021; accepted April 8, 2021. 
$\mathrm{R}$ esearchers have advocated for early childhood teachers to use language and literacy assessment data to inform instruction (e.g., Kincaid, McConnell, \& Wackerle-Hollman, 2020; Lonigan, Allan, \& Lerner, 2011; Piasta, 2014; Stecker, Lembke, \& Foegen, 2008) based on evidence that planned, targeted instruction positively affects student language and literacy outcomes (Connor et al., 2009; Denton et al., 2010; Denton, Fletcher, Anthony, \& Francis, 2006; Fuchs, Fuchs, \& Stecker, 2010; Lonigan \& Phillips, 2016; Simmons et al., 2011; Slavin, Cheung, Holmes, Madden, \& Chamberlain, 2013) and that teacher training interventions incorporating the use of language and literacy data have led to improved outcomes for young children (e.g., Al Otaiba et al., 2011; Landry, Anthony, Swank, \& Monseque-Bailey, 2009; Lembke et al., 2018; Marsh, Bertrand, \& Huguet, 2015; Weiland \& Yoshikawa, 2013). As a result, the gathering of information from myriad data sources has become an increasing focus in early childhood education via policy initiatives (Center on Standards \& Assessment Implementation, 2016; Quality Compendium, 2020; K. Snow, 2011; U.S. Department of Education, 2011) and recommendations from the field regarding best practices in early childhood education (Bowman, Donovan, \& Burns, 2001; Kostelnik, Soderman, Whiren, \& Rupiper, 2019; National Association for the Education of Young Children [NAEYC], 2009).

Policy and best practice guidance regarding assessments are premised on the idea that teachers will use such data to inform instruction (Marsh et al., 2015; Young \& Kim, 2010). Indeed, the key lies in the assumption that teachers do something with data after they are gathered, as underscored by attention to data use as a component of assessment validity in the standards for educational and psychological testing (APA Task Force on Psychological Assessment and Evaluation Guidelines, 2020). K. Snow (2011) called this an "interconnected system of decisions and activity" (p. 11). Others have conceptualized this process as sensemaking, in which teachers engage with data to interpret and use them (or not) in instruction (Bertrand \& Marsh, 2015; Coburn \& Turner, 2012; Vanlommel \& Schildkamp, 2019).

However, despite the increased emphasis on data gathering (e.g., via quality rating and improvement systems), there is limited information about how preschool teachers engage with language and literacy data, what we and others refer to as teachers' data practices (Bradbury, 2014; Gischlar \& Vesay, 2018; Little, 2012). This is a critical gap in achieving the 
intended benefits of increasing teachers' access to and use of data (Dorn, 2010). Thus, in this study, we sought to understand preschool teachers' perspectives on their language and literacy data practices. Next, we describe the types of data sources available to preschool teachers and summarize the literature investigating the connections between teachers and language and literacy data.

\section{Language and Literacy Data Sources for Preschool Teachers}

Although teachers increasingly have access to a variety of data sources (i.e., tools and ways of gathering data) regarding children's language and literacy skills, there are multiple ways to conceptualize these sources, which are described in various ways throughout the literature. In a seminal work regarding language and literacy assessment in early childhood, Lonigan et al. (2011) differentiated between informal and standardized assessments. Informal assessments were described by Lonigan et al. as involving teachers' observations of children and can include data collected via documented observations of children, checklists, rating scales, and portfolios. These are deemed informal because they are not standardized in their administration, scoring, or interpretation procedures. To conduct informal assessments, teachers gather data from observations of children engaging in the setting to document their language and literacy development and learning; such documentation often takes the form of creating portfolios (e.g., collecting writing samples to show development of emergent writing skills) or rating the extent to which certain abilities are mastered, emerging, or not yet demonstrated (e.g., GOLD; Teaching Strategies, n.d.). This category of assessment is quite broad and encompasses a variety of data sources that are often considered integral components of preschool education. For example, the use of portfolios or visual documentations of children's learning are hallmarks of early childhood education (Edwards, Hamel, Leeper Miller, \& Ren, 2020; Hall et al., 2010; Katz, Chard, \& Kogan, 2014; NAEYC, 2009). Sometimes, data gathered through informal assessments may not be formally documented but simply noted and remembered by the teacher. Some researchers have referred to this skill as a type of teacher expertise (Erickson, 2011; Mason, 2011), wherein teachers "notice and interpret what is happening in one's classroom (Berliner, 1994; Frederiksen, 
1992; Mason, 2002)" (van Es \& Sherin, 2006, p. 125).

In contrast, standardized assessments, according to Lonigan et al. (2011), are those that have common and consistent (i.e., standardized) administration, scoring, and interpretation procedures. These assessments are more formal in their procedures. Standardized assessments include screening assessments to identify children's initial skills and possible need for additional assessment or support (e.g., Denver II: Frankenburg, Dodds, \& Archer, 1990; Get Ready to Read! Revised [GRTR-R]: Whitehurst \& Lonigan, 2009), progress-monitoring assessments that allow for repeated assessment over time (e.g., Ages \& Stages Questionnaires- 3; Squires, Twombly, Bricker, \& Potter, 2009), and diagnostic assessments that provide in-depth information about specific skills (e.g., BRIGANCE Inventory of Early Development III Standardized; Curriculum Associates, n.d.).

There are, of course, other ways to conceptualize data sources, many of which overlap with Lonigan et al.'s (2011) conceptualization of assessment. These include summative and formative assessments (Dorn, 2010; Klute, Apthorp, Harlacher, \& Reale, 2017), curriculum-based assessments (Akers et al., 2014; Dorn, 2010; Grisham-Brown, Hallam, \& Pretti-Frontczak, 2008), teacher-created assessments (Gischlar \& Vesay, 2018), teacher noticing (Cherrington \& Loveridge, 2014; van Es \& Sherin, 2002), and intuitive data (Vanlommel \& Schildkamp, 2019). In sum, there are a variety of language and literacy data sources that preschool teachers could have access to, each providing different types of information about children. However, less is known about which data sources teachers are using to gather data. When examining preschool teachers' language and literacy curriculum and assessment use, Gischlar and Vesay (2018) found that a quarter of teachers surveyed reported gathering data about children's early literacy skills via standardized assessments, with the rest of the participants (74.4\%) relying on teachercreated measures. Similarly, Carson and Bayetto (2018) found that less than a quarter of preschool teachers regularly collected data about children's phonological awareness skills, often relying on informal assessments when doing so. Thus, there is evidence that preschool teachers gather data from these myriad sources but may rely more on informal assessments. 


\section{Preschool Teachers' Language and Literacy Data Practices}

As previously stated, data are not just to be collected but are intended to be interpreted and used in some way to inform practice (Bertrand \& Marsh, 2015; Coburn \& Turner, 2012; K. Snow, 2011). Yet, the literature regarding both what preschool teachers know from language and literacy-related data and what they do with data after gathering-their collective data practices-is limited. For example, although Gischlar and Vesay (2018) investigated the measures to which teachers had access, the researchers did not examine how teachers used those data.

A handful of studies concerning preschool teachers' data use has provided insight into data practices. Regarding language and literacy specifically, Carson and Bayetto (2018) found that teachers used phonological awareness data for progress monitoring and guiding planning for instruction. Most of the research, however, has focused on data use more generally. For instance, Zweig, Irwin, Kook, and Cox (2015) interviewed preschool directors and teachers and found that they were collecting data within their preschool programs but faced many challenges in using the data, including integrating across data sources and interpreting the data. Similarly, Brawley and Stormont (2014) surveyed preschool teachers and found that they generally agreed with statements regarding the importance of data-informed practices (e.g., "I use recorded data to make decisions about a child"; p. 106). However, in contrast to these beliefs, teachers reported low frequencies of data practices. Finally, in an ethnographic study of four teachers, Bradbury (2014) observed that teachers favored grounding their knowledge of children in observations and information gathered through everyday interactions. Teachers valued this knowledge gained from informal assessments, in contrast to standardized assessments, which required a large time commitment and were potentially viewed as devaluing teachers' judgments. Similar patterns have been found in data practices of teachers in early elementary grades, with evidence that kindergarten teachers focused on knowing the children in their classroom, prioritizing this type of knowledge over standardized assessment data (Barnes, Fives, Brighton, \& Moon, 2019), and that teachers in lower grades were less comfortable with standardized measures (Zhang \& Burry-Stock, 2003).

Complicating understandings of preschool teachers' language and literacy data practices is that these often have been examined within 
paradigms constructed by researchers (e.g., Carson \& Bayetto, 2018; Gischlar \& Vesay, 2018) rather than from teachers' perspectives. In other words, researchers have used their orientations to assessment, often developed from the extant literature, to study teachers' data practices via deductive research approaches. This may not align with teachers' orientations to assessment or connect to teachers' day-to- day experiences in their classrooms. As a result, this may limit what can be learned about the data sensemaking process (Bertrand \& Marsh, 2015). Indeed, there is evidence that how teachers perceive of instruction may differ from how researchers view instruction (Munby, 1982; Schachter, Matthews, \& Piasta, 2021). Furthermore, Yeager, Bryk, Muhich, Hausman, and Morales (2013) argued that the data teachers need to gather are different from those gathered by researchers or policymakers, and as such, the types of data preschool teachers are using may not be adequately captured by the field. Finally, most of the studies have not examined the multiple contexts or settings in which teachers engage and make use of language and literacy data, which is particularly important when understanding practice (Cohen, Raudenbush, \& Ball, 2003; Lampert, 2010; Lee, 2014; Yeager et al., 2013).

\section{The Current Study}

Research to date has indicated that teachers are gathering a variety of data, but there continues to be little understanding of their data practices as a whole (Akers et al., 2014), including how teachers make sense of data (Bertrand \& Marsh, 2015) and use data in their practice. This is critically important for understanding how language and literacy data are and can be used to support teachers' practice and children's learning outcomes. The purpose of this study was to build a theory regarding preschool teachers' language and literacy data practices, focusing on teachers' perspectives of the data sensemaking process. We conducted a multicase study (Yin, 2014) and generally followed Eisenhardt's (1989) recommendations for building theories from case study research. 


\section{Method}

\section{Theoretical Framework for Understanding Preschool Teachers' Data Practices}

Bertrand and Marsh (2015) proposed that during the sensemaking process, teachers must transform collected data into usable information, which becomes integrated into their existing expertise and knowledge. Bertrand and Marsh argued that only after this process do data become something that can be acted on to inform instruction. Two important data-sensemaking processes are planning for and enacting instruction. However, although enacted instruction is visible to observers, the thinking and reasoning behind planning and instruction are not readily visible. To understand how teachers make sense of data to inform their data practices, it is necessary to gain access to their internal processes. Thus, we focused on teachers' pedagogical reasoning (Horn, 2015; Nilsson, 2009; Shulman, 1987), or the process of making decisions using knowledge to enact practice. Focusing on pedagogical reasoning allows access to the variety of internal processes in which teachers engage.

We used a phenomenological approach (Creswell, 2007; Marton, 1981) to understand teachers' perspectives regarding their data practices. Critical to a phenomenological approach is collecting observations of the phenomenon (first order; language and literacy assessment and instruction in this study), as well as participants' perspectives regarding the phenomenon of interest (second order; data practices in this study). Focusing on teachers' perspectives allowed us to understand teachers' varied data practices as these are enacted in individual contexts (Cohen et al., 2003; Lampert, 2010; Schachter, 2017).

\section{Participants}

To select cases, we focused on a specific population and purposively sampled (Eisenhardt, 1989; Maxwell, 2013) preschool teachers who had access to language-and literacy-related assessment data. In total, 20 teachers (see Table 1) from two U.S. states in the Midwest region participated in the study. Most participants were female $(n=18)$ and taught in a variety of preschool settings, including Head Start, public prekindergarten, a university-affiliated program, and a parochial school. Six teachers held 
Table 1 Participant Information and Data Practices Profile

\begin{tabular}{|c|c|c|c|c|c|c|}
\hline Profile & Pseudonym & Education & $\begin{array}{l}\text { Years of } \\
\text { experience }\end{array}$ & Program format & Curriculum & $\begin{array}{l}\text { Reported } \\
\text { assessments }\end{array}$ \\
\hline \multirow[t]{8}{*}{ Data gatherer } & Emma & $\begin{array}{l}\text { BA in elementary } \\
\text { education }\end{array}$ & 0.5 & Private, full day & Creative Curriculum & GOLD \\
\hline & Hailey & BA in education & 7 & Head Start, full day & Creative Curriculum & $\begin{array}{l}\text { Denver II, } \\
\text { kindergarten readiness } \\
\text { assessment checklist, } \\
\text { GOLD }\end{array}$ \\
\hline & Holly & $\begin{array}{l}\text { BA in early childhood } \\
\text { education, MA in early } \\
\text { childhood }\end{array}$ & 3.5 & Private, full day & Creative Curriculum & GOLD \\
\hline & Lacey & BA in psychology with an & 3 & Parochial, half day & $\begin{array}{l}\text { School based, } \\
\text { thematic, and } \\
\text { teacher created }\end{array}$ & $\begin{array}{l}\text { School summative } \\
\text { assessment }\end{array}$ \\
\hline & & early childhood focus & 2 & Private, full day & Creative Curriculum & GOLD \\
\hline & Melinda & $\begin{array}{l}\text { BA in secondary education, } \\
\text { working on MA in early } \\
\text { childhood }\end{array}$ & & & & \\
\hline & Michelle & $\begin{array}{l}\text { AA, working on BA in } \\
\text { education }\end{array}$ & 8 & Head Start, half day & Creative Curriculum & $\begin{array}{l}\text { GOLD, state learning } \\
\text { standards }\end{array}$ \\
\hline & Travis & $\begin{array}{l}\text { BA in education, } \\
\text { pre-K-3 endorsement, } \\
\text { pre-K-5 reading endorsement }\end{array}$ & 6 & Public school, half day & $\begin{array}{l}\text { School based and } \\
\text { teacher created }\end{array}$ & $\begin{array}{l}\text { School summative } \\
\text { assessment }\end{array}$ \\
\hline \multirow[t]{7}{*}{$\begin{array}{l}\text { In-the-moment } \\
\text { data user }\end{array}$} & Bess & $\begin{array}{l}\text { Bachelor's degree in early } \\
\text { childhood }\end{array}$ & 20 & Head Start, half day & Creative Curriculum & $\begin{array}{l}\text { Denver II, kindergarten } \\
\text { readiness assessment } \\
\text { checklist, GOLD, } \\
\text { Get Ready to } \\
\text { Read! Revised }\end{array}$ \\
\hline & Eli & $\begin{array}{l}\text { AA in early childhood } \\
\text { development }\end{array}$ & 4 & Private, full day & Creative Curriculum & $\begin{array}{l}\text { Ages \& Stages } \\
\text { Questionnaires, GOLD, } \\
\text { Get Ready to Read! } \\
\text { Revised }\end{array}$ \\
\hline & Kasey & BA in elementary education & 7 & Parochial, half day & $\begin{array}{l}\text { School based, } \\
\text { thematic, and } \\
\text { teacher created }\end{array}$ & $\begin{array}{l}\text { School summative } \\
\text { assessment }\end{array}$ \\
\hline & Macey & $\begin{array}{l}\text { BA in early childhood } \\
\text { education }\end{array}$ & 0.75 & Private, full day & Creative Curriculum & GOLD \\
\hline & Roseanne & $\begin{array}{l}\text { AA in early childhood } \\
\text { education }\end{array}$ & 15 & Parochial, half day & Creative Curriculum & $\begin{array}{l}\text { School summative } \\
\text { assessment }\end{array}$ \\
\hline & Sheila & CDA, BA in psychology & 25 & Private, full day & Creative Curriculum & GOLD \\
\hline & Valencia & $\begin{array}{l}\text { BA in early childhood } \\
\text { education }\end{array}$ & 2 & Private, half day & Creative Curriculum & $\begin{array}{l}\text { GOLD, Get Ready to } \\
\text { Read! Revised }\end{array}$ \\
\hline
\end{tabular}


Table 1 Participant Information and Data Practices Profile (continued)

\begin{tabular}{|c|c|c|c|c|c|c|}
\hline Profile & Pseudonym & Education & $\begin{array}{l}\text { Years of } \\
\text { experience }\end{array}$ & Program format & Curriculum & $\begin{array}{l}\text { Reported } \\
\text { assessments }\end{array}$ \\
\hline \multirow[t]{6}{*}{$\begin{array}{r}\text { Integrated } \\
\text { data user }\end{array}$} & Abigail & $\begin{array}{l}\text { CDA, BA in early } \\
\text { childhood studies }\end{array}$ & 20 & Head Start, full day & Creative Curriculum & $\begin{array}{l}\text { Denver II, kindergarten } \\
\text { readiness assessment } \\
\text { checklist, GOLD, Get Ready } \\
\text { to Read! Revised }\end{array}$ \\
\hline & Janice & $\begin{array}{l}\text { BA in secondary music } \\
\text { and English, MA in early } \\
\text { childhood curriculum and } \\
\text { instruction }\end{array}$ & 30 & Parochial, half day & $\begin{array}{l}\text { School based, } \\
\text { thematic, and } \\
\text { teacher created }\end{array}$ & $\begin{array}{l}\text { School summative } \\
\text { assessment }\end{array}$ \\
\hline & Latisha & $\begin{array}{l}\text { BA in early childhood } \\
\text { development, BA in social } \\
\text { work }\end{array}$ & 12 & Head Start, full day & Creative Curriculum & $\begin{array}{l}\text { Ages \& Stages } \\
\text { Questionnaires, } \\
\text { Denver II, GOLD, } \\
\text { Get Ready to Read! } \\
\text { Revised }\end{array}$ \\
\hline & Ruth & $\mathrm{CDA}$ & 2 & Public school, full day & Play based & $\begin{array}{l}\text { BRIGANCE Inventory } \\
\text { of Early Development, } \\
\text { GOLD, self-created } \\
\text { letter/number } \\
\text { assessment, Get Ready } \\
\text { to Read! Revised }\end{array}$ \\
\hline & Solange & CDA & 5.5 & Head Start, half day & Creative Curriculum & $\begin{array}{l}\text { Kindergarten readiness } \\
\text { assessment checklist, } \\
\text { Denver II, GOLD }\end{array}$ \\
\hline & Valerie & $\begin{array}{l}\text { AA in early childhood } \\
\text { development, some BA } \\
\text { coursework }\end{array}$ & 12 & Head Start, full day & Creative Curriculum & $\begin{array}{l}\text { Kindergarten readiness } \\
\text { assessment checklist, } \\
\text { Denver II, GOLD }\end{array}$ \\
\hline
\end{tabular}

Note. $\mathrm{AA}=$ associate of arts degree; $\mathrm{BA}=$ bachelor of arts degree; $\mathrm{CDA}=$ Child Development Associate Credential; $\mathrm{MA}=$ master of arts degree.

associate's degrees, and 14 held bachelor's degrees, all in early childhood or related fields. Generally, teachers' backgrounds represented the diversity of the U.S. early childhood workforce, with each type of setting requiring different qualifications for teachers (Whitebook, McLean, Austin, \& Edwards, 2018). Teachers worked with children from a diverse range of racial, ethnic, and socioeconomic backgrounds.

Teachers also had access to GOLD ( $n=15$; Teaching Strategies, n.d.; also referred to by participants as TSG), GRTR-R ( $n=12$; Whitehurst \& Lonigan, 2009), school/ teacher-created assessments $(n=6)$, 
a kindergarten readiness assessment checklist $(n=5)$, Denver II $(n=$ 4; Frankenburg et al., 1990), Ages \& Stages Questionnaires-3 ( $n=2$; Squires et al., 2009), and BRIGANCE Inventory of Early Development III Standardized ( $n=1$; Curriculum Associates, n.d.). Most participants used the Creative Curriculum (Dodge, Colker, \& Heroman, 2002; $n=15$ ), which is a commercially published curriculum widely used in U.S. preschool classrooms (Schachter, Piasta, \& Justice, 2020) and commonly paired with GOLD; the remaining teachers used school-and/ or teacher-generated curricula. Both the Creative Curriculum and the state and federal jurisdictions within which teachers worked provided expectations regarding children's language and literacy learning (Nebraska Department of Education, 2018; Ohio Department of Education, 2019; Schachter, Piasta, \& Justice, 2020; Administration for Children \& Families, 2015). These general expectations included planning and implementing language and literacy activities to support children's growth across the domains of listening and understanding, speaking and communicating, phonological awareness, alphabet knowledge, book knowledge, print awareness, and early writing; specific scopes and sequences of instruction, however, are not provided or required. All participants' names, including children's, in this article are pseudonyms.

\section{Data Collection}

To build our cases of teacher data practices, we conducted three sets of observations and interviews with teachers. All observations and interviews were conducted by the first author.

\section{Observations}

Teachers selected the days on which they wanted to be observed. As there were no time constraints for sampling, data collection occurred across the school year and with an average of 43 days between the first and third observations $(M=22.67$ days, range $=8-88$ days $)$. The observations lasted for the duration of the main academic time of the day as defined by the teacher. Observations ranged from 59 to 133 minutes across participants ( $M=97$ minutes, $S D=20$ minutes) and included activities such as teacher-facilitated large-group and small-group time, as well as less structured choice time when teachers engaged in language 
and literacy instruction and addressed other content areas (e.g., creative arts, math). During each observation, the researcher video recorded the teacher and took field notes. Table 2 provides more information about the focus of these observations and examples of commonly observed language and literacy practices across classrooms. Individual examples of practice described subsequently are representative of the practices generally observed across data collection.

\section{Interviews}

The first author conducted two types of interviews with teachers across the three rounds of data collection: planning interviews and stimulated recall interviews. As we were trying to balance collecting unbiased data regarding teachers' perceptions and their data practices, we used interview protocols that were initially open-ended and narrowed over time (see the Appendix for the full interview protocol). Specifically, in the first round of interviews, the first author did not directly ask about data practices, whereas in the third round of interviews, she focused only on data practices. All interview protocols were designed to provide multiple opportunities for teachers to potentially discuss data practices. All interviews were video recorded.

\section{Planning Interviews}

The purpose of planning interviews was to understand how language and literacy data informed teachers' planning. Prior to the beginning of each observation, teachers were asked about their plans for the day, with a specific focus on language and literacy activities. A follow-up question was then asked regarding why they planned those specific activities. In the second and third interviews, the follow-up question directly asked teachers whether data informed their planning. Planning interviews were also used to conduct the stimulated recall interviews by identifying instances when teachers deviated from their stated plan (see Table 2 and the Appendix).

\section{Stimulated Recall Interviews}

The purpose of the stimulated recall interviews was to understand how data informed teachers' pedagogical reasoning about their instruction. Each teacher participated in three stimulated recall interviews (one following each observation), for a total of 60 interviews across all teachers. 
Table 2 Criterion Sampling for Stimulated Recall Interview

\begin{tabular}{|c|c|c|}
\hline Visual cue & Rationale & Example from the data \\
\hline $\begin{array}{l}\text { The teacher deviates from } \\
\text { the plan described during } \\
\text { the planning interview. }\end{array}$ & $\begin{array}{l}\text { Could indicate that the } \\
\text { teacher was thinking about } \\
\text { data that would lead to that } \\
\text { decision (Fogarty, Wang, } \\
\text { \& Creek, 1983; Gilbert, } \\
\text { Turdel, \& Haughian, 1999; } \\
\text { McAlpine, Weston, } \\
\text { Berthiaume, \& Fairbank- } \\
\text { Roch, 2006) }\end{array}$ & $\begin{array}{l}\text { The teacher skips the story } \\
\text { read-aloud during circle } \\
\text { time. (Hailey) }\end{array}$ \\
\hline $\begin{array}{l}\text { Child error or } \\
\text { question/exclamation }\end{array}$ & $\begin{array}{l}\text { Teachers must reason about } \\
\text { whether or how they will } \\
\text { respond to an error or } \\
\text { question; plans have been } \\
\text { interrupted, and teachers } \\
\text { may need to use various } \\
\text { types of information/data } \\
\text { in order to decide how or } \\
\text { whether to respond to the } \\
\text { child (Parker \& Gehrke, } \\
\text { 1984). }\end{array}$ & $\begin{array}{l}\text { A child mislabels the letter } \\
r \text { as } a \text {. }\end{array}$ \\
\hline $\begin{array}{l}\text { The teacher pulls children } \\
\text { into small group or works } \\
\text { one-on-one with a child. }\end{array}$ & $\begin{array}{l}\text { May be using specific } \\
\text { information/data about } \\
\text { individual children in } \\
\text { these smaller groupings }\end{array}$ & $\begin{array}{l}\text { The teacher calls a group of } \\
\text { three children over to play a } \\
\text { rhyming game. (Eli) }\end{array}$ \\
\hline $\begin{array}{l}\text { The teacher uses } \\
\text { assessment data. }^{\text {a }}\end{array}$ & $\begin{array}{l}\text { Visual evidence that the } \\
\text { teacher is using data in } \\
\text { some way }\end{array}$ & $\begin{array}{l}\text { The teacher is using letter } \\
\text { cards to have children name } \\
\text { letters and letter sounds. } \\
\text { (Janice) }\end{array}$ \\
\hline $\begin{array}{l}\text { The teacher focuses on } \\
\text { an emergent language } \\
\text { and/or literacy skill. }\end{array}$ & $\begin{array}{l}\text { Focused on practices related } \\
\text { to reading comprehension, } \\
\text { vocabulary, oral language, } \\
\text { alphabet knowledge, print } \\
\text { awareness, and phonological } \\
\text { awareness targeted in early } \\
\text { learning standards and } \\
\text { assessed in research } \\
\text { measures (National Early } \\
\text { Literacy Panel, 2008; Smith, } \\
\text { Brady, \& Anastasopoulos, } \\
\text { 2008; Ohio Department of } \\
\text { Education, 2019). }\end{array}$ & $\begin{array}{l}\text { The teacher opens the book } \\
\text { reading by asking, "Do you } \\
\text { remember what happened in } \\
\text { this story?" (Sheila) } \\
\text { The teacher holds a child's } \\
\text { hand as he forms letters. } \\
\text { (Kathy) }\end{array}$ \\
\hline
\end{tabular}

a. Rare in the data; if not present, replaced by an additional observation of the teacher focusing on a language and literacy skill.

b. Given the focus of the study, we sampled two of these occurrences. 
In stimulated recall, teachers view videos of their practice and describe their internal processes during instruction (Schachter \& Freeman, 2015). In this study, the researcher uploaded the classroom observation video to her laptop. Then, the researcher and the teacher sat in front of the laptop and coviewed the recordings of the classroom observation. In conjunction with the interview protocol (see the Appendix), the video served as the stimulus for helping the teacher recall her or his thinking in the moment of instruction. This method avoids interrupting teaching (Gass \& Mackey, 2000; Shavelson \& Stern, 1981) while still providing opportunities to understand teachers' pedagogical reasoning during teaching (Dwyer \& Schachter, 2020). To preserve memory and stimulate recall of in-the- moment thinking, rather than reflection on practice, these interviews were as close in time to the observation as possible. All but one of the 60 interviews were conducted on the same day as the corresponding observation, with the one interview occurring the following day but still within recommended time frames (Bloom, 1953).

To select points of stimulus for the interviews, we used multiple sampling methods to identify moments of instruction to coview. These involved criterion-based, time-based, and participant-initiated sampling (Schachter \& Freeman, 2015). We developed the criterion-based sampling using the extant literature and hypotheses as to when a teacher might be using data to inform language and literacy instruction. These criteria, as well as the rationale for their inclusion, are presented in Table 2. This criterion-based sampling ensured that a minimum number of data points regarding language and literacy instruction per participant were available for generating the cases. The instances derived from the criterion-based sampling were identified prior to the stimulated recall interview, as the researcher conducted the observation. During the interview, the video was specifically stopped at those points to elicit teachers' pedagogical reasoning.

Time-based and participant-initiated sampling also occurred during the coviewing of the video. Given the length of the observations $(M=97$ minutes), it was impractical for teachers to view the entirety of the video. Thus, a five-minute time-based sampling procedure was also used, wherein the researcher and the teacher coviewed one minute of instruction, and then the researcher forwarded the video five minutes and started the video again, allowing the teacher to stop the video during that time to discuss points of interest. Finally, teachers 
were encouraged to stop the video at any moment of instruction that was interesting or out of the ordinary (both during the time sampling and throughout the entire video). This sampling method increased the representativeness of teachers' perspectives on their practice, which are critical to the phenomenological approach (Clark \& Yinger, 1977; Gatbonton, 2008).

At points when either the researcher (criterion-based sampling) or the teacher (time-based or participant-initiated sampling) stopped the video, teachers were asked to describe their internal processes relevant to the activities on the video following the protocol provided in the Appendix. All questions in the first interview were open-ended, without any direct reference to language and literacy data. During the first round of interviews, we noted that teachers were often describing information that they knew about children without specifying how they knew it. Hypothesizing that this information might be derived from data, an additional question regarding how teachers knew information was added to the second and third interviews. This type of modification to research protocols is typical and recommended in theory-generating research (Eisenhardt, 1989). More direct questions regarding data as connected to language and literacy instruction were used in the second and third interview protocols.

\section{Analyses}

Both authors engaged in the data analysis process. This was beneficial because the first author collected the data, providing her a deep insight into participants and their perspectives, and the second author had a more distanced perspective on the data. Following our phenomenological approach, we examined teachers' perspectives on their data practices. Thus, we entered the process of data analyses by first identifying our definitions of data and then setting these aside to focus on teachers' descriptions of their data practices. A critical step in this process was recognizing our own biases regarding data as coming from formal and observational assessments, and that this perspective might be different from that of teachers. 


\section{Data Preparation}

All interviews were transcribed verbatim. However, for the purposes of this article, we removed fillers (e.g., "um," "like") for ease of reading. For the stimulated recall interviews, observational data concerning the moment of instruction discussed by the teachers in their responses were added to the transcripts to provide descriptive, first-order data. These were used in contextualizing and interpreting the teachers' pedagogical reasoning.

\section{Within-and Cross-Case Analyses}

We used an inductive approach to develop a framework grounded in the data for conceptualizing teachers' data practices (Eisenhardt, 1989; Maxwell, 2013). We then used this framework to create individual cases and then conduct a cross-case synthesis (Yin, 2014).

Both authors began analyses by independently reviewing individual transcripts for each teacher; we read within each set of participants' transcripts (interviews 1-3) first and then read across participants. We each wrote memos and reflected on initial ideas about the data. After independent review, we met to discuss our emerging ideas regarding data practices. At this point, we engaged in an iterative process of considering the interview data to understand how teachers defined data. We observed that teachers did not necessarily talk about language and literacy data. Rather, they described knowing a great deal about children, knowledge or information that had to come/be gathered from somewhere. This pattern was observed early on in data analyses. Because teachers were not explicitly referencing data within their planning or pedagogical reasoning, we had to start with what they knew about children. From this starting point, we could identify the data source supporting such knowledge, both from teachers' descriptions and from the additional prompts added in the second and third interviews (see the Appendix). This was a critical component in developing the framework because it shaped our understanding of data practices more holistically. For these teachers, data were something they knew about a child (information). Because the idea of data was not explicit in the teachers' reports, we had to make inferences from two constructs that teachers were describing (information and information gathering). 


\section{Table 3 How Teachers Gathered Data About Children}

\begin{tabular}{|c|c|c|}
\hline Data source & Definition & Example \\
\hline Informal noticing & $\begin{array}{l}\text { Most common source of data. } \\
\text { From what teachers } \\
\text { anecdotally noticed about } \\
\text { children; based on teachers' } \\
\text { priorities and not } \\
\text { documented. }\end{array}$ & $\begin{array}{l}\text { "From all the-all the-from } \\
\text { previous lessons and activities that } \\
\text { we've done together." (Travis) }\end{array}$ \\
\hline $\begin{array}{l}\text { Documented } \\
\text { observations }\end{array}$ & $\begin{array}{l}\text { Second most common source } \\
\text { of data. From observations } \\
\text { about children that are } \\
\text { documented in some manner } \\
\text { (frequently via GOLD). }\end{array}$ & $\begin{array}{l}\text { "Well, everything that I do when I } \\
\text { was doing-I do that is an } \\
\text { observation for me, which is part } \\
\text { of our assessments. We do our } \\
\text { observations, and then we put our } \\
\text { observations in Teaching } \\
\text { Strategies [GOLD]." (Abigail) }\end{array}$ \\
\hline Formal assessments & $\begin{array}{l}\text { Rarely used source of data. } \\
\text { From standardized } \\
\text { assessments capturing } \\
\text { language and literacy skills; } \\
\text { most were not language } \\
\text { and literacy specific. }\end{array}$ & $\begin{array}{l}\text { "I did a Denver on him also, } \\
\text { so I know what his baseline is." } \\
\text { (Solange) }\end{array}$ \\
\hline
\end{tabular}

Based on teachers' conceptualization of data and our case analyses, we identified a framework of data practices that consisted of three major elements: what teachers knew, how they knew it, and the way they used the data. We then revisited the individual transcripts to confirm and elaborate this theory (Maxwell, 2013). Our final working understandings of these elements along with examples from the data are presented in Tables $\mathbf{3}$ and $\mathbf{4}$ and are described in more detail in the Findings section. Importantly, we found that teachers discussed topics beyond what we might typically consider connected to language and literacy (e.g., children's interests); however, these were meaningful for teachers in describing their data practices and are thus included here as relevant.

After identifying the framework for teachers' data practices, we then revisited each individual teacher (case) to identify any instance when teachers described data or data use. In total, participants made 357 individual references to data/using data across the interviews $(M=23.05$, $S D=7.44$, range $=13-40$ ). Notably, only 214 of these references were specific to knowledge about children's language and literacy skills. For each instance in each interview for each teacher, we documented what 
Table 4 How Teachers Used Data

\begin{tabular}{|c|c|c|}
\hline Data profile & Definition & Example \\
\hline $\begin{array}{l}\text { Interacting in } \\
\text { the moment }\end{array}$ & $\begin{array}{l}\text { Data informed the way } \\
\text { teachers engaged children } \\
\text { or responded to children. }\end{array}$ & $\begin{array}{l}\text { “Always providing the kids with } \\
\text { new vocabulary ... he's going to } \\
\text { kindergarten, he's going into the } \\
\text { world, they're building their } \\
\text { vocabulary so that they can build } \\
\text { their conversations and their } \\
\text { communication. Plus, he's } \\
\text { Spanish-speaking, English as a } \\
\text { second language, and he loves to } \\
\text { speak English now, whereas when } \\
\text { he first came, he would only speak } \\
\text { Spanish. He uses both languages, } \\
\text { English and Spanish, so I give him } \\
\text { as many English words as I can, } \\
\text { whenever I get that opportunity." } \\
\text { (Abigail) }\end{array}$ \\
\hline Planning & $\begin{array}{l}\text { Data informed determinations } \\
\text { of instructional content, } \\
\text { activities, or grouping, with } \\
\text { these decisions made ahead } \\
\text { of time. }\end{array}$ & $\begin{array}{l}\text { “And we've been working on } \\
\text { rhyming words, and in our TSG, } \\
\text { which is Teaching Strategies } \\
\text { [GOLD], that's where we score low } \\
\text { at with our children, in those } \\
\text { areas in literacy. So, I try to make } \\
\text { sure there's a lot of literacy and } \\
\text { rhyming words and-in-in the } \\
\text { story and talk about rhyming } \\
\text { words." (Bess) }\end{array}$ \\
\hline $\begin{array}{l}\text { Differentiating } \\
\text { activities }\end{array}$ & $\begin{array}{l}\text { Data informed the ways } \\
\text { teachers planned or adjusted } \\
\text { activities to meet the learning } \\
\text { needs of individual children. }\end{array}$ & $\begin{array}{l}\text { "Trinity is very bright. She can } \\
\text { actually read.... wants to do } \\
\text { everything very quickly and get it } \\
\text { over with so she can go play. So, } \\
\text { she's a little bit immature in that } \\
\text { way.... Austin has done that. I } \\
\text { would've let it slide because that's } \\
\text { where he is. I'm expecting this } \\
\text { from her cuz this is where she is. } \\
\text { I'm expecting this from Austin } \\
\text { because this is where he is.” (Ruth, } \\
\text { describing her thinking about } \\
\text { children as they write on chart } \\
\text { paper to transition out of large- } \\
\text { group time) }\end{array}$ \\
\hline
\end{tabular}


they knew, how they knew it, and the way they used data in accordance with the framework. This gave us an individual understanding of each teacher's data practices. Then, we conducted a cross-case synthesis (Yin, 2014) to identify broader patterns across teachers' data practices. As will be described further, we observed three patterns, which we call profiles, of teacher data practices: data gatherers, in-the- moment data users, and integrated data users. As part of this process, we revisited each case to review the data practices and quantify teachers' references to relevant data practices (e.g., references to language-and literacy-specific data) and, when appropriate, calculated the frequency of those data practices. Teachers with similar patterns were grouped into their respective profile. Table 1 indicates the profile for each participant.

\section{Trustworthiness of Data and Interpretation}

We took multiple steps to ensure trustworthiness of data and interpretation. The first author was intensely involved with the research participants (teachers) via multiple classroom observations and interviews. During data collection, she engaged in peer debriefing with the second author to ensure accuracy (Creswell \& Creswell, 2018). Overall, this process allowed for the generation of rich data that were detailed and varied enough to describe the phenomenon (Maxwell, 2013). After the creation of the data practices framework, we conducted member checking with five $(25 \%)$ of our original participants to confirm and elaborate our data practices framework. Finally, extensive field notes and memos were generated to maintain an audit trail of all research procedures and decisions, including data collection and analyses (Guba \& Lincoln, 1989).

\section{Findings}

As this study was exploratory in nature and focused on a relatively unexamined phenomenon in preschool education, several key findings regarding teachers' data practices emerged. These included understanding teachers' perspectives of data, the development of a framework of data practices, and profiles of teacher data practices based on the framework. 


\section{Teachers' Perspectives of Data}

As described in the Method section, a critical component of our analyses was identifying how teachers conceptualized data. We found that teachers defined data in a practical way as information about children. This is exemplified in a comment from Ruth: "I just know my children, period. It is just something that you have to be there. You have to be there in their play, in their free choices to know what their interests are, to know what they know." Here, she pointed out that teachers need to know what children know. For teachers, this idea translated into data being points of information, such as how Holly explained knowing about a child:

Not necessarily assessment data but just kind of anecdotal data that I know about the child as a whole...the relationship that I have with the child and what I know works for him and things that're really important to him.

Thus, for this study, we identified data as any information that teachers had about children in their classrooms. Importantly, this operationalization is consistent with the Merriam-Webster's Online Dictionary definition of data (n.d.) as "factual information (such as measurements or statistics) used as a basis for reasoning, discussion, or calculation" (def. 1). In other words, what teachers knew constituted their data.

\section{Data Practices Framework}

Our data practices framework comprised three major elements: what teachers knew, how they knew it, and the way they used the data. Importantly, all three constructs of the framework were interlinked. In other words, what teachers knew or how they knew something was directly connected to how they used those data in their practice. As such, we included all the components in the framework to accurately represent teachers' data practices.

\section{What Teachers Knew}

We observed that teachers knew a great deal of information that was integral to their instruction. This ranged from data about children in 
their classrooms to other types of important information about context and children's development. This included knowledge about a variety of topics: children's interests, children's skills in multiple domains, how children learned best (both those in their classroom and children generally), learning goals for children, kindergarten expectations, teachers' own previous classroom experiences, and how to keep children engaged. For example, as Ruth noted, "in kindergarten they need to sound things out in order to be successful. Sarah's at the point of where she knows most of her letters, so she's beginning to associate sounds with them." Here, Ruth demonstrated what she knew about this particular child's literacy skill development (letter knowledge), a continuum for the child's skill development (letter-sound knowledge), and knowledge regarding what is expected in kindergarten (context, curriculum, and child development). This multifaceted knowledge was a common pattern in the data.

Overall, $60 \%$ of individual references to data/data use included teachers' knowledge about children's language and literacy skills $(n=214)$, whereas $40 \%$ of references referenced other types of knowledge that teachers held $(n=143)$ despite occurring during language-and literacyrelated instruction. For example, when describing her reasoning about a child who made an error in identifying rhyming sounds, Emma said, "That's a younger friend. He just transitioned a couple of months ago, but he's on the younger end of transitioning," attributing the error to age rather than specific language and literacy skills. This was common in the data; even when asked about language-and literacy-related activities, teachers did not necessarily describe knowledge about children's language and literacy skills.

When teachers discussed children's language and literacy skills, the specificity of knowledge varied across teachers in terms of their knowledge about the whole class generally versus individual children. In the previous example from Ruth, she demonstrated knowledge of a specific child, Sarah, and the specific sequence of skill development. Bess identified an area of language and literacy in need of development for her whole class:

We focus on rhyming words, and that's in the area where they don't get a lotta that. So, my goal is try to get them familiar with rhyming words. And we've been working on rhyming 
words, and in our TSG [GOLD], which is teaching strategies, that's where we score low at with our children, in those areas in literacy.

Here, Bess's focus was on the entire class, in comparison with Ruth, who focused on an individual child.

Additionally, we observed that teachers reported knowing a great deal about children's interests. Indeed, all teachers described having information about children's interests, and this was considered valuable data both for planning and instruction. As Holly described,

We take into account the things that they're interested in. And we really wanna get-we choose what we're gonna study based on that. And so I feel like that really gets a lot of buy-in for the kids. And I think one of the most important things in early childhood is to get kids really excited about learning and excited about coming to school. And when we choose something that they're interested in, then they're way more likely to kind of be engaged and kind of buy what you're selling, basically.

This was further highlighted in Sheila's explanation regarding her lack of surprise about a child's knowledge of the word igloo: "He's interested in reading books and looking at pictures-knowing that he just probably saw it in a book or something or talked with Mom and Dad." Here, her knowledge of the child's vocabulary came from understanding his interest in reading.

Importantly, our findings mirror those of previous work identifying the multifaceted and complex knowledge that teachers have about children, including interests (e.g., Lee, 2014; Schachter, 2017). More importantly, these findings were an entrée into understanding teachers' data practices, including how teachers knew information about children and how teachers used those data in practice.

\section{How Teachers Knew}

How teachers had data about children was particularly important in considering their language and literacy data practices. There were three sources for gathering data about children: through informal noticing, 
documented observations, and formal assessments. These are presented in Table 3, along with definitions and examples. Notably, we grouped these sources based on the best fit with our data and the sources and gathering practices that emerged. The categories overlap with those in extant literature but do not completely align with one specific view of data (e.g., Dorn, 2010; Klute et al., 2017; Lonigan et al., 2011; Vanlommel \& Schildkamp, 2019).

Informal noticing seemed to be the most common source for teachers to learn about children, and this type of data gathering happened anecdotally throughout teachers' interactions with children. For example, Travis reported that his knowledge about a child's skills came from "all the previous lessons and activities that we've done together." Here, his knowledge developed from noticing children's skills over time. These were differentiated from documented observations, which involved some type of systematic data gathering. These were the second most common sources for learning about children and included use of observational tools such as GOLD (Teaching Strategies, n.d.). This type of data source was evident in statements such as the one from Bess previously, indicating that she knew about her children's rhyming from "in our TSG [GOLD]." The third type of data gathering involved formal assessments, including standardized assessments such as GRTR-R (Whitehurst \& Lonigan, 2009) or the Denver II (Frankenburg et al., 1990); this also included teacher-and school-created assessments. These were considered formal because they had common, standardized procedures for administration and interpretation. Importantly, although teachers had access to a variety of documented and formal data sources (see Table 1), we found that teachers most frequently reported gathering data specifically about children's language and literacy skills from informal noticing (92\% of instances, $n=214$ references to language and literacy data). Language-and literacy-related data gathered from documented observations and formal assessments were used less frequently $(11 \%, n=23$, and $13 \%, n=28$, respectively; in some instances, multiple data sources were used and thus do not total 100\%).

\section{How Teachers Used Data}

Across participants, we noted three patterns in the way teachers used data to inform their practice: interacting in the moment with children, 
planning for instruction, and differentiating activities for children (see Table 4 for definitions and examples). Most teachers used data in the moment, what some might term teachable moments or unplanned moments, to initiate interactions with children or to respond to children in some way. A prototypical example of responding was when a child asked Solange if she had written her name on her paper, and Solange responded by pointing to the child's name. Solange explained her pedagogical reasoning about pointing to the child's name: "I was kind of hoping that she would understand...she can just barely identify her name, let alone write it, cuz she also has a fine-motor delay." Here, Solange used her knowledge of the child's name-writing skills to respond in the moment to a child. An example of initiating was when Valerie asked her class, "Did you know wiggle and worm start with a $W$ ?" She explained her pedagogical reasoning: " $W$ is a tricky word-a tricky letter. Sometimes they'll call it a $M$. Sometimes they'll get the $M$ and the $W$ mixed up-just doing a little literacy in there." She then went on to explain that based on a kindergarten readiness assessment checklist they used, she knew that $W$ was a letter that many children in her class could not identify. Thus, she drew attention to the letter during a circle time activity. It is also important to note that in this example, Valerie drew on two data sources in her reasoning. These were data from informal noticing that sometimes children confuse $M$ and $W$ and data about letter identification from a formal kindergarten readiness assessment checklist. Importantly, in $73 \%$ of cases in which teachers specifically described using knowledge about language and literacy, it was to interact in the moment with children.

In contrast to the common use of data in the moment to initiate or respond to children, teachers less often reported using data in advance of interactions to plan activities and instruction. For example, Ruth described planning an activity in which children made letters with their bodies, specifically targeting $T$ and $V$ because she had just collected data on children's alphabet knowledge and observed that "a third of my kids didn't know what a $T$ was...a lot of them didn't know what a $V$ was." Thus, using data, she planned to include the letter activity in her whole-group instruction. Only $20 \%$ of references to language and literacy data were used to support teachers' planning.

Finally, some teachers described using data to differentiate instruction for individual children. Specifically, these were instances when 
teachers tailored their practice based on what they knew about individual children. For example, Janice reported that she had some kids reading. In her pedagogical reasoning, she described selecting specific beginning reader books and how she used those books with children based on what she knew about their reading. As she described, "I have several kids reading now, and so I only have one set of the extreme beginner ones [books]...this one was just a little bit tough for him....So, he and I will work on it a little bit at school before this one goes home." Again, we noted differences in the frequency of these data use practices, with teachers only describing using language and literacy data to differentiate instruction in $11 \%$ of instances.

\section{Profiles of Teachers' Data Practices}

In conducting our cross-case analyses, although we considered all aspects of the framework, we observed that differences across teachers emerged around data use specifically, resulting in three groups or profiles of teachers' data practices. Next, each profile is described and exemplified with prototypical cases. We focus on how teachers reported using what they knew from different data sources within their pedagogical reasoning to inform practice. Additionally, although teachers' pedagogical reasoning and practice extended across the academic domains, for the purpose of this study, we focused only on language and literacy.

\section{Data Gatherers}

Importantly, all teachers in the study were gathering data. For some teachers ( $n=7$; see Table 1), however, this was the extent of their data practices. They rarely described using data to inform their instruction. Indeed, they seemed to place a strong emphasis on the data collection process-data gathering. As Emma described, "some of it's just kind of mental documentation we're keeping track of, but then, after the fact on a couple of the activities per week, we do go back in and make documentations on our curriculum site." This idea of gathering data, mostly via noticing and documenting, was present throughout these teachers' pedagogical reasoning; however, they rarely discussed how gathered data were used in their practice. This is not to say that we 
anticipated that teachers would always use data to inform their practice. Yet, for this profile of teachers, we observed rare discussion of a connection between the practices of data gathering and data use. For example, in describing whether data informed her response to a child volunteering the word Ryan as a $B$ word after another child had given the response "Bryan," Emma returned to the idea of data gathering, not data use, and said, "Maybe not necessarily in that exact moment. I could go back and make an observation about it." Here, she talked about the potential for this as a documentation but not in thinking about her instruction. This was a similar pattern in data gatherer responses in which teachers described knowing about assessments and thinking about opportunities to gather data, often for GOLD, but this was not connected to their practice.

The result of this emphasis on the data-gathering process was that these data did not seem to be connected to teachers' planning or pedagogical reasoning during instruction. A prototypical example of this was when Melinda was observed spelling out children's names when selecting classroom helpers during circle time. When asked about her reasoning for spelling, she said,

That's just our routine. We spell 'em out. I don't really know why. It started before I was in the classroom, so I just continued with it, but to be able to recognize what their name is, spelled out, so they can gain that skill, as well, and hopefully have that accomplished by the time they head to kindergarten...that is an expectation they're expected to be able to write their first name and last initial as they enter kindergarten.

Here, Melinda incorporated knowledge about kindergarten expectations and classroom routines, yet she did not discuss what information (data) she had about children's letter identification or name-writing skills as part of her pedagogical reasoning in this moment, nor in her plan for instruction. This pattern was evident for the data gathers; although they had access to the data they collected, it did not seem to inform their language and literacy practice in the moment or in planning for or differentiating instruction. In other words, these teachers were doing assessment but not using data. 


\section{Table 5 Example From In-the-Moment Data User Eli}

\begin{tabular}{|c|c|}
\hline Interview type and context & Teacher response \\
\hline $\begin{array}{l}\text { Planning: Describing his } \\
\text { plans for language and } \\
\text { literacy instruction }\end{array}$ & $\begin{array}{l}\text { "... a bunch of different phonological awareness activities. } \\
\text { There is only one, free playing kind of thing...so I have } \\
\text { activities planned, but around the different areas, I don't } \\
\text { know when I'm gonna do it." "I've just been doing a lot with } \\
\text { phonological awareness, and it's something that they are in- } \\
\text { terested in, like the small games that I do." }\end{array}$ \\
\hline $\begin{array}{l}\text { Stimulated recall: The teacher } \\
\text { pulled aside a boy who was } \\
\text { struggling with a rhyming } \\
\text { activity to work with him } \\
\text { one-on-one. }\end{array}$ & $\begin{array}{l}\text { "I think I initially brought him over there for rhyming, } \\
\text { but he was just so into the beginning sounds. Those } \\
\text { cards, some of them did rhyme, but a lot of them were } \\
\text { beginning sounds, matching, and separating, stuff like } \\
\text { that, so I wanted him to do the activity again, just to try to re- } \\
\text { assure what he knows. I think he did a chart, and that was } \\
\text { not-that wasn't planned at all. But, I don't know, just some- } \\
\text { thing-he just seemed very interested in beginning sounds } \\
\text { but also just the manipulating and playing and sounding out } \\
\text { all the words. I just wanted to keep that going." }\end{array}$ \\
\hline
\end{tabular}

In-the-Moment Data Users

The in-the- moment data users were the second profile of teachers ( $n=$ 7). For these teachers, we observed that they depended on data in the moment to initiate interactions with children and to respond to children. Often, the data these teachers relied on were from informal noticing. One exemplar of this is Eli's discussion of his plan and then discussion of his pedagogical reasoning in the moment, presented together in Table 5.

In this example, Eli described his planning for the day based on a variety of things that he knew about the context (curriculum and child interests), but he did not report drawing on data regarding children's phonological awareness skills to develop the plan. In contrast, he described using informal noticing data during instruction. The quotes here and in Table 5 describe his pedagogical reasoning about the end of one of the small-group phonological awareness activities, after which he pulled aside a child who was having difficulty with rhyming. Eli reported responding to the child in the moment using what he noticed in two ways. First, Eli identified that he wanted to follow up with the child whom he observed was having difficulty rhyming in the activity. Second, Eli described being contingent and switching to focusing on initial sounds to follow the child's focus. Eli further explained that his reasoning was 
based on "nothing that I have concrete or in his file or anything, but just in that moment." Thus, although no documented or formal language and literacy data seemed to inform Eli's planning, informal noticing data about the child's language and literacy skills were used to respond in the moment.

The teachers who fit this profile were typically focused on informal noticing data to support their practice in the moment. In the case of Eli, he was responding to a particular child based on what he was seeing the child do. In a different example, Macey initiated a question with a small group of children: "Do you remember what a little baby polar bear is called?" Her reasoning here was based on noticing data about children's learning from what they "talked about last week," but this was not connected to her planning for the day.

Overall, the teachers in this profile typically relied on informal noticing to respond to children mostly during in-the- moment instruction. Importantly, teachers in this profile described understanding the role of data, as exemplified by Bess:

We have to assess a lot. I mean, in this agency, we do a lotta assessments. And we have to see what they know to take them to the next step. When we find out what they know, we know how to scaffold it to take them to the next area, phase, learning phase.

Here, she demonstrated a recognition that data are to be used to support children's development; however, this idea of using data to support children was mostly evident during moments of instruction, rather than for planning or differentiating instruction ahead of time.

\section{Integrated Data Users}

In this profile, we observed teachers $(n=6)$ using multiple data sources for multiple purposes. Importantly, these teachers were integrating across data sources and uses consistently-not only for in-the- moment instruction but also for planning and differentiating instruction for children. One example of this can be seen across Valerie's planning and pedagogical reasoning at multiple points during one observation, presented in Table 6. 


\section{Table 6 Example From Integrated Data User Valerie}

\begin{tabular}{|c|c|}
\hline Interview type and context & Teacher response \\
\hline $\begin{array}{l}\text { Planning: Describing her plan } \\
\text { for the writing center }\end{array}$ & $\begin{array}{l}\text { “... practice writing because after we did their } \\
\text { assessments, some of them-a lot of them that are going to } \\
\text { kindergarten - still can't write their names and form their } \\
\text { letters, so I wanted to do ... the ones that were going to kin- } \\
\text { dergarten that are more advanced, I have their names writ- } \\
\text { ten in little blocks [rectangles on the top of the page, one for } \\
\text { each letter in the name]. Caleb already knows how to write } \\
\text { his name, so his name was just written on the paper, but then } \\
\text { on the backside of his, he has numbers. ... Then, for your } \\
\text { friends, like Raul, Nora, and Marcus, their name [is] writ- } \\
\text { ten on the paper at the top just so I know it's theirs, and then } \\
\text { they can just write any way they want to cuz they're 3, and } \\
\text { they're really not required to form letters and things, so it's } \\
\text { pretty much still open-ended for them.” }\end{array}$ \\
\hline $\begin{array}{l}\text { Stimulated recall: A child } \\
\text { brought her paper from } \\
\text { the writing center to show } \\
\text { Valerie the numbers she } \\
\text { had written. }\end{array}$ & $\begin{array}{l}\text { "When we did the observation with her with numbers, } \\
\text { some numbers she didn't know, and for her to write them } \\
\text { by herself without me even encouraging it or anything, } \\
\text { that's pretty cool .... She didn't write them left to right. She } \\
\text { wrote them right to left ... it shows her fine-motor skills in } \\
\text { the way she printed them, so she did pretty good. That was } \\
\text { impressive to me." }\end{array}$ \\
\hline $\begin{array}{l}\text { Stimulated recall: Valerie } \\
\text { called a specific child to } \\
\text { come work with her in } \\
\text { the writing center. }\end{array}$ & $\begin{array}{l}\text { "We do the Denver [II] ... and he couldn't draw. Then, } \\
\text { the fact that he couldn't draw, it made me say, 'OK, } \\
\text { we're gonna work on his fine-motor skills and his writing } \\
\text { skills.' That's why we're working on his-and, again, I didn't } \\
\text { have a guideline for him to go by [rectangle boxes]. It was } \\
\text { pretty much whatever he wanted to write, but he just wanted } \\
\text { to write his name, so he asked me to help him with it, but I } \\
\text { already know that he can write his name pretty good. That's } \\
\text { why I tried to help him. I said, 'OK, now let me see you try by } \\
\text { yourself,' and then he wrote it by himself." }\end{array}$ \\
\hline
\end{tabular}

In this exemplar, Valerie had planned a differentiated writing activity based on data collected from a formal assessment regarding children's name-writing abilities. She incorporated different scaffolds for children based on where they were developmentally and their age to differentiate instruction. During instruction, as many children interacted with both the writing activity and with Valerie, she continued to use data to inform her pedagogical reasoning in the moment. When the child brought her work to show Valerie, she described this as a moment when the child moved beyond her expectations and demonstrated new 
knowledge. Here, Valerie used informal noticing to identify that the child had advanced in her writing, thus integrating a new data source. Later, when she called a child to come write with her, Valerie reported using her knowledge about the child-data gained from formal assessment and informal noticing - to initiate the activity with him, as well as respond to his request for support and encourage him to write independently. She also referred to the way she had differentiated the activity for different learners, in that this child had a free-form paper as compared with his peers who had more structured writing tasks. In this example, in contrast to the in-the- moment data users, data informed Valerie's planning, differentiating, and in-the- moment instruction. Furthermore, she integrated multiple data sources across her pedagogical reasoning, something unique to teachers in the integrated data users profile.

Another example of this is from Ruth's explanation of the individual tasks she had created for children to do in their journals. One child was working on $H$ and $N$ because she had gotten them wrong on a teachercreated measure (formal assessment) of alphabet knowledge. Ruth explained her pedagogical reasoning:

I was trying to get her to grasp that letter before she moves on to kindergarten. She got everything but $H$ and $N$. I don't know why. She writes "Nan-Nan" all the time because that's what she calls her grandma. She writes "Nan-Nan" all the time. I'm like, "That's a N." She goes, "Oh, I know."

Here, Ruth integrated knowledge from both informal noticing (about the child writing "Nan-Nan") and her formal assessment (the child's performance on $H$ and $N$ on the teacher-created measure of alphabet knowledge). Importantly, Ruth was trying to reconcile the child's performance across these two data sources to consider the best instructional practices.

As a final example, Abigail described specifically pulling three children of different ages $(3,4$, and 5 years $)$ to work together in a small group on rhyming so she could assess their rhyming skills. During the activity, she initiated an interaction with the children to make sure that they understood the target words so they could do the rhyme correctly, and she also allowed the two older children to support the youngest child in rhyming, based on what she knew about each child's development. 
When asked about how assessment informed her pedagogical reasoning, Abigail described the entire activity as

influenced by assessment, because not only-like I said, my assessment is the observation, but I go back, and I write it down. And then, I go over it and assess it again to find out where we need to go or what has changed from my last assessment, so at this particular point, in this activity or when I do a small group like that, it's all about me assessing.

Here, Abigail was using data to learn where children were, track change, and think about planning. Thus, she described a cyclical process of integrating data use.

\section{Discussion}

The purpose of this study was to develop a theory based on preschool teachers' perceptions regarding data practices and thus contribute new knowledge about teachers' data practices to the field. We found that data practices comprised what teachers knew about children, how teachers knew that information, and the subsequent use of the data and that these practices were interconnected. Additionally, we found three distinct teacher profiles for these data practices. Through the generation of this theory, we were able to amplify teachers' perspectives, gain a better understanding of how data are used in preschool classrooms, and identify critical considerations for the field. Next, we focus on these key findings/critical considerations and their implications for research, policy, and practice, with an emphasis on moving from doing assessment to using assessment.

\section{Data May Be Different for Teachers}

A key finding from this study was that participants seemed to consider any information they held about children to be data. From their responses to the questions specifically about assessment data, it was clear that the teachers were considering data broadly, often including children's interests and contextual information in their conceptualiza-

tions of data. This aligns with the findings of other research highlighting 
the complexity of preschool teachers' knowledge (Bradbury, 2014; Lee, 2014; Schachter, 2017), while also demonstrating a potential disconnect between how teachers and researchers may be considering data. Participants' views of data as any information about children move beyond the typical understanding of assessment data as focused on "children's developmental progress and status and how well they are learning" (C.E. Snow \& Van Hemel, 2008, p. 18) to include other information. Specifically, teachers viewed informal noticing, documented observations, or standardized assessments as sources for information/data (subsequently discussed). This is critically important because the data serve as the foundation for subsequent practices and data sensemaking (Bertrand \& Marsh, 2015), and how teachers view data is an important lens for understanding policies and initiatives concerning data. Indeed, for teachers in the in-the- moment and integrated data users profiles, what and how they knew about children was directly connected with their data use. Thus, more efforts are needed to align views of what constitutes data, as what the source of data is and the information derived from that source have important implications for what teachers can learn and know about the children in their classrooms.

We observed that one type of information that was particularly important for teachers in the study was information about children's interests. Teachers frequently reported children's interests as data and considered this information integral in both their planning and their pedagogical reasoning. This conceptualization of children's interests as data, although possibly beyond the boundaries of what researchers consider to be data, is indicative of predominant theoretical orientations to early childhood education - that planning be emergent and follow children's interests (Hall et al., 2010; Katz et al., 2014; NAEYC, 2009) —and aligned with the underpinnings of the curricula used by participants in the study (Schachter, Piasta, \& Justice, 2020). Such orientations necessitate knowledge of children's interests, as teachers may need information about interests to plan for and engage in language and literacy instruction. This aligns with Yeager et al.'s (2013) assertion that, at least in part, teachers use different data than researchers and policymakers do. Understanding the role of knowledge about children's interests and how this functions with other types of data merits further exploration and understanding, particularly in the context of efforts to improve knowledge specific to children's language and literacy skills. 
Relatedly, we observed that the specificity of teachers' knowledge about children's language and literacy skills varied; who they had knowledge about, their whole class or individual children, also varied. This is important because this type of knowledge was used by teachers to both plan and support in-the- moment instruction. Whereas there is empirical evidence that specific knowledge about individual children's skills can support practices, particularly differentiated instruction, and improve child learning (Connor et al., 2009; Denton et al., 2006, 2010; Fuchs et al., 2010; Lonigan \& Phillips, 2016; Simmons et al., 2011; Slavin et al., 2013), how specific this knowledge should be is unknown. Furthermore, there is a need for teachers to understand children's skills at the classroom level to effectively plan and implement instruction (Kostelnik et al., 2019; NAEYC, 2009). Thus, this is also worthy of further investigation, as it has implications for how teachers plan and how they are reasoning about their data.

\section{Teachers May Have Alternative Conceptualizations of Data Sources}

Another key finding from this study is that the ways data sources have been conceptualized in the past are not completely in alignment with the patterns we found in teachers' reported data sources. These data sources overlapped with sources that others have identified (e.g., Akers et al., 2014; Grisham-Brown et al., 2008; Lonigan et al., 2011; Vanlommel \& Schildkamp, 2019), but reflected these preschool teachers' orientations to data, a relatively unexplored phenomenon to date (Dorn, 2010). Although data sources have been conceptualized in different ways by researchers, often contrasting formal and informal (Lonigan et al., 2011) or summative versus formative (Dorn, 2010; Klute et al., 2017) data, teachers in our study described three types of data sources. There were two distinct ways of gathering data within what Lonigan et al. (2011) conceptualized as informal sources, with informal noticing described as a distinct process from gathering documented observations. Each source of data held a separate place in teachers' data practices. Notably, the predominant type of data gathered via informal noticing aligns with some literature regarding teachers' expertise and ability to identify and interpret what is happening in their classroom through noticing (Erickson, 2011; Mason, 2011), thus underscoring their value for teaching. Additionally, there was very little discussion of assessments as summative 
and formative or differentiation between varying uses of formal assessments (e.g., screening, progress monitoring, diagnostic assessment). Such data sources were mentioned less frequently by teachers, and all seemed to be gathered and serve similar, limited functions in their planning and pedagogical reasoning.

It is important to note that all teachers who participated in the study were gathering data from more traditionally acknowledged assessment data sources, such as documented observations or standardized measures-assessments that are typically incorporated into policies regarding data use (Center on Standards \& Assessment Implementation, 2016; Quality Compendium, 2020; K. Snow, 2011; U.S. Department of Education, 2011), recommended by the field (Edwards et al., 2020; Hall et al., 2010; Katz et al., 2014; NAEYC, 2009), and even aligned with their curriculum (i.e., GOLD). However, the data from these assessments did not seem to play a large role in teachers' data practices; in a sense, this constituted another instance of doing assessment rather than using data to inform instruction. When specifically considering teachers' knowledge regarding children's language and literacy skills, most data were gathered via informal noticing, with documented observations and formal data sources less frequently used by teachers as a means for learning about children's skills. This finding is similar to that of Barnes et al. (2019), who found that kindergarten teachers were focused on knowing their children rather than relying on formal, standardized assessment data, and mirrors the practices encouraged by researchers as part of teacher noticing (e.g., Cherrington \& Loveridge, 2014; van Es \& Sherin, 2002).

In some ways, this makes sense because these data are more easily gathered in busy classroom settings. However, researchers studying noticing data have often focused on training teachers to both notice and use those data in meaningful ways (for a comprehensive review, see Gaudin \& Chaliès, 2015). Given this emphasis, it is likely that teachers would need support in gathering and using these data in productive ways. Relatedly, Lonigan et al. (2011) cautioned that informal assessments might not assist teachers in understanding children's development of specific skills across language and literacy domains because of the lack of systematicity and the minimal guidance as to how to interpret these data. This is mirrored in findings by Miller-Bains, Russo, Williford, DeCoster, and Cottone (2017), who found that an observation-based assessment 
did not help teachers differentiate between the skill levels and learning needs of children within their classrooms. Furthermore, others have cautioned that these types of observations might be biased by opportunities to see children demonstrate certain skills but not others (e.g., K. Snow, 2011). Finally, it should be noted that there have been mixed findings regarding the accuracy or trustworthiness of teachers' judgments about children's skills outside of formal and standardized assessments. In a meta-analysis of 75 studies, Südkamp, Kaiser, and Möller (2012) found only a moderate correlation between teachers' judgments and students' skills. In a more recent review, Urhahne and Wijnia (2021) found that, across studies, teachers tended to correctly identify children's academic skills but with accuracy diminishing for lower performing students. Importantly, Urhahne and Wijnia noted patterns of bias in teachers' judgments based on gender, racial identity, and socioeconomic status. Thus, these types of judgments should not be the only source of data gathering regarding children's skills.

That is not to say that teachers should solely depend on standardized or formal data or use such data in isolation from informal noticing or documented observation data. Notably, participants in our study who regularly drew on data to inform multiple aspects of practices also used multiple sources of data, such that their knowledge about children's language and literacy skills was integrated across informal noticing, documented observations, and formal assessments. This balancing and integrating across various data sources to generate a comprehensive understanding of children's learning and development aligns with recommended competencies and practices for preschool teachers (NAEYC, 2020; NAEYC \& National Association of Early Childhood Specialists in State Departments of Education, 2003). In this way, teachers were able to move beyond the required data gathering to data interpretation or sensemaking.

\section{There Is a Continuum in Teachers' Data Use Practices}

The generation of this theory allowed us to see that there is a continuum in teachers' data use practices that range from doing assessment, to in-the- moment data use, to integrated data use. This is critical because a key component of assessment is the use of data to make decisions about and enact instruction (Bertrand \& Marsh, 2015; Coburn \& 
Turner, 2012; NAEYC, 2020; K. Snow, 2011; Young \& Kim, 2010), and generally, teachers' use of data was limited. Specifically, a third of the teachers never moved beyond data gathering-doing assessment-to sensemaking with their language and literacy data. Similarly, the inthe- moment data users were also less developed in their data practices. Whereas they moved beyond simply gathering data, their data use was limited to initiating and responding to children during instruction. This type of contingent responsivity to children in the moment is a critical component of high-quality early childhood education (Cabell et al., 2011; Kostelnik et al., 2019; Landry, Smith, Miller-Loncar, \& Swank, 1997; NAEYC, 2020) yet does not fully capitalize on the potential of data to support children's learning. Thus, these teachers were missing a critical step in their data practice and potentially undersupporting children's development. This finding that few teachers were integrating or using data for a variety of practices is aligned with emerging evidence that teachers do not use data frequently and have difficulty in integrating across data sources (Brawley \& Stormont, 2014; MillerBains et al., 2017; Zweig et al., 2015). Thus, together with the existing literature, our findings suggest that teachers may need more support to move beyond doing assessment to interpreting data and using data to inform multiple aspects of practice.

Importantly, only the third profile of data use, integrated data users, aligns with the views from theory, research, and practice stipulating how data are to be used. Through using stimulated recall and focusing on teachers' perspectives and pedagogical reasoning, we were able to see the complex thinking needed to bring about these complex data practices (Schachter, Freeman, \& Parakkal, 2020), particularly the use of data. These integrated data users provide insight into the potential of data use in early childhood classrooms. In this integrated model of data practices, teachers relied on all of their data sources to plan for and differentiate language and literacy instruction. The data sensemaking exhibited by these teachers offers a potential model of data practices that could support high-quality language and literacy instruction and positive outcomes for children. These teachers were able to use their deep contextual knowledge of children gathered through informal noticing and documented observations along with their formal assessment data to plan for and enact language and literacy instruction that differentiated based on the learning needs of individual children. This is important because 
it demonstrates how the purpose of using data can be achieved in practice and through the sensemaking process. More research is needed to understand whether these data practices can be linked to children's language and literacy outcomes.

As a field, we need to do a better job of supporting teachers to move from doing assessment to integrated data use, all while attending to the fact that teachers must use data to reason within their unique classroom contexts. Teachers need more training on how to use and interpret data sources to inform different aspects of instruction, including planning, in-the- moment interactions, and differentiation. Additionally, training should emphasize the interconnectedness of data gathering, data knowledge, and data use. This should happen in both preservice and inservice learning opportunities and can be facilitated through supporting teachers to reflect and engage in pedagogical reasoning with data (e.g., Cherrington \& Loveridge, 2014; de Vocht, 2015; Flynn \& Schachter, 2017; Souto-Manning, 2010). Such efforts should focus on all three sources of data and recognize the strengths and weaknesses of various data sources (including the potential for bias), as well as how to integrate across data sources and the types of knowledge that each affords. Furthermore, as a field, we may need to consider why teachers typically favor informal noticing data sources over others so we can both capitalize on this knowledge and shift practices toward more data integration. In doing so, we can support teachers in moving away from doing assessment to using assessment in ways that are meaningful for practice and children's language and literacy outcomes.

\section{Limitations and Future Directions}

There are some limitations to this work that lead to direct implications for future research. First, because the purpose of this study was to describe teachers' data practices, we do not know how these data practices are aligned with instructional quality or children's outcomes. Furthermore, because we were focused solely on teachers' perspectives, we do not know the reliability or fairness of their data gathering, trustworthiness of or bias in their data interpretation, or appropriateness of their enacted practices based on those data. Thus, more work is needed to understand how these practices and profiles are associated with language and literacy instruction and learning. 
Additionally, more research is needed to understand how teacher and setting characteristics influence or inform data practices. Although robust for addressing our research goals, our sample size precluded drawing too many conclusions regarding the influence of teacher characteristics on data practices. It should be noted that we did not observe discernible patterns of differences in teacher background characteristics across data profiles; however, there is reason to hypothesize that teachers' experiences specifically connected to training on using data, as well as program-level expectations, could inform data practices (Al Otaiba et al., 2011; Landry et al., 2009; Lembke et al., 2018; Marsh et al., 2015; Weiland \& Yoshikawa, 2013). These patterns did not appear in our data, but we did not ask teachers directly about these experiences, so this may not have emerged in their responses. Additionally, given the evidence in the literature of potential biases in teacher judgments based on the cultural and linguistic diversity of both children and teachers (GardnerNeblett \& Ebright, 2021; Mills, Moore, Chang, Kim, \& Frick, 2021; Südkamp et al., 2012; Urhahne \& Wijnia, 2021), this merits further investigation in understanding teachers' data practices.

Relatedly, only two types of curricula were represented: the Creative Curriculum (Dodge et al., 2002) and teacher/school-created curricula. More research is needed to explore the connection between curricula and data practices, as it is likely that these could function in interconnected ways (Kostelnik et al., 2019; NAEYC, 2020). Notably, the GOLD assessment used by most participants included gathering of documented observations, data which were reported relatively infrequently in teachers' pedagogical reasoning about their practice. Some teachers, mostly the integrated data users, referenced data gathered in documented observations, yet many teachers reported gathering documented observations only as something to input into their documentation system.

\section{Conclusion}

By employing rigorous qualitative methods, we explored a relatively unresearched phenomenon from participants' perspectives and provide a much needed framework for understanding preschool teachers' data practices. We acknowledge that these teachers' perspectives may not reflect recommended assessment practices (APA Task Force on Psychological Assessment and Evaluation Guidelines, 2020). However, knowing 
how teachers understand data, data gathering, and data use is important as a basis for effectively communicating about these topics and considering how to shift data practices in ways that better support children's language and literacy learning.

Although more work is necessary to understand the application and generalizability of these practices across other teachers and contexts (Maxwell, 2013), our study provides a robust understanding of our participants' experiences and is critical in highlighting how practicing teachers enact data practices set forth in policy and research. Indeed, our findings demonstrate the flaws in the way current policies are enacted, such that they have facilitated the doing of assessment and not necessarily the use of assessment. Although preschool teachers hold deep knowledge of the children in their classrooms, teachers' data practices may not be achieving the intended outcomes of policy initiatives. If we, as a field, expect data-related policies to achieve positive language and literacy impacts for teachers and children, we must better support teachers through professional learning opportunities that meet teachers where they are and build from their strengths and current practices. We hope that our framework provides a basis for engaging in such work, as well as an impetus for further research as to how to do this and what can happen when preschool teachers engage in complex integrated data practices.

Acknowledgments We thank the Spencer Foundation for supporting this research.

\section{References}

Administration for Children and Families. (2015). Head Start early learning outcomes framework: Ages birth to five. Washington, DC: Office of Head Start, Administration for Children \& Families, U.S. Department of Health \& Human Services.

Akers, L., Del Grosso, P., Atkins-Burnett, S., Boller, K., Carta, J., \& Wasik, B.A. (2014). Tailored teaching: Teachers' use of ongoing child assessment to individualize instruction: Vol. II. A review of the literature. Washington, DC: Office of Planning, Research, and Evaluation, Administration for Children and Families, U.S. Department of Health and Human Services.

Al Otaiba, S., Connor, C.M., Folsom, J.S., Greulich, L., Meadows, J., \& Li, Z. (2011). Assessment data-informed guidance to individualize kindergarten reading instruction: Findings from a cluster-randomized control field trial. The Elementary School Journal, 111(4), 535-560. https://doi.org/10.1086/659031 
APA Task Force on Psychological Assessment and Evaluation Guidelines. (2020). APA guidelines for psychological assessment and evaluation. Washington, DC: American Psychological Association.

Barnes, N., Fives, H., Brighton, C.M., \& Moon, T.R. (2019). Literacy teachers' beliefs about data use at the bookends of elementary school. The Elementary School Journal, 119(3), 511-533. https://doi.org/10.1086/701655

Bertrand, M., \& Marsh, J.A. (2015). Teachers' sensemaking of data and implications for equity. American Educational Research Journal, 52(5), 861-893. https://doi. org/10.3102/0002831215599251

Bloom, B.S. (1953). Thought-processes in lectures and discussions. The Journal of General Education, 7(3), 160-169.

Bowman, B.T., Donovan, M.S., \& Burns, M.S. (2001). Eager to learn: Educating our preschoolers. Washington, DC: National Academy Press.

Bradbury, A. (2014). Early childhood assessment: Observation, teacher 'knowledge' and the production of attainment data in early years settings. Comparative Education, 50(3), 322-339. https://doi.org/10.1080/03050068.2014.921371

Brawley, S., \& Stormont, M.A. (2014). Investigating reported data practices in early childhood: An exploratory study. Journal of Positive Behavior Interventions, 16(2), 102-111. https://doi.org/10.1177/1098300713480838

Cabell, S.Q., Justice, L.M., Piasta, S.B., Curenton, S.M., Wiggins, A., Pence Turnbull, K., \& Petscher, Y. (2011). The impact of teacher responsivity education on preschoolers' language and literacy skills. American Journal of Speech-Language Pathology, 20(4), 315-330. https://doi.org/10.1044/1058-0360(2011/10-0104)

Carson, K., \& Bayetto, A. (2018). Teachers' phonological awareness assessment practices, self-reported knowledge and actual knowledge: The challenge of assessing what you may know less about. The Australian Journal of Teacher Education, 43(6), 67-85. https://doi.org/10.14221/ajte.2018v43n6.5

Center on Standards \& Assessment Implementation. (2016). Pre-kindergarten and kindergarten assessments. Retrieved from https://csaa.wested.org/wp-content/ uploads/2020/02/CSAI-Update PreK-KAsessments.pdf

Cherrington, S., \& Loveridge, J. (2014). Using video to promote early childhood teachers' thinking and reflection. Teaching and Teacher Education, 41, 42-51. https://doi.org/10.1016/j.tate.2014.03.004

Clark, C., \& Yinger, R. (1977). Research on teacher thinking. Curriculum Inquiry, 7(4), 279-304. https://doi.org/10.1080/03626 784.1977.11076224

Coburn, C.E., \& Turner, E.O. (2012). The practice of data use: An introduction. American Journal of Education, 118(2), 99-111. https://doi.org/10.1086/663272

Cohen, D.K., Raudenbush, S.W., \& Ball, D.L. (2003). Resources, instruction, and research. Educational Evaluation and Policy Analysis, 25(2), 119-142. https://doi. org/10.3102/01623737025002119

Connor, C.M., Piasta, S.B., Fishman, B., Glasney, S., Schatschneider, C., Crow, E., ... Morrison, F.J. (2009). Individualizing student instruction precisely: Effects of Child $\times$ Instruction interactions on first graders' literacy development. Child Development, 80(1), 77-100. https://doi.org/10.1111/j.1467-8624.2008.01247.x 
Creswell, J.W. (2007). Research design: Qualitative, quantitative, and mixed methods approaches. Thousand Oaks, CA: Sage.

Creswell, J.W., \& Creswell, J.D. (2018). Research design: Qualitative, quantitative, and mixed methods approaches (5th ed.). Thousand Oaks, CA: Sage. Curriculum Associates. (n.d.). BRIGANCE Inventory of Early Development III Standardized. North Billerica, MA: Author.

Data. (n.d.). In Merriam-Webster's online dictionary (11th ed.). Retrieved from https://www.merriam-webster.com/dictionary/data

Denton, C.A., Fletcher, J.M., Anthony, J.L., \& Francis, D.J. (2006). An evaluation of intensive intervention for students with persistent reading difficulties. Journal of Learning Disabilities, 39(5), 447-466. https://doi.org/10.1177/0022219406039 $\underline{0050601}$

Denton, C.A., Nimon, K., Mathes, P.G., Swanson, E.A., Kethley, C., Kurz, T.B., \& Shih, M. (2010). Effectiveness of a supplemental early reading intervention scaled up in multiple schools. Exceptional Children, 76(4), 394-416. https://doi.org/10.1177/ $\underline{001440291007600402}$

de Vocht, L. (2015). Reconceptualising teacher-child dialogue in early years education as a moral answerability. International Journal of Early Childhood, 47, 317-330. https://doi.org/10.1007/s13158-015-0140-2

Dodge, D.T., Colker, L.J., \& Heroman, C. (2002). The Creative Curriculum for preschool. Washington, DC: Teaching Strategies.

Dorn, S. (2010). The political dilemmas of formative assessment. Exceptional Children, 76(3), 325-337. https://doi.org/10.1177/001440291007600305

Dwyer, J., \& Schachter, R.E. (2020). Going beyond defining: Preschool educators' use of knowledge in their pedagogical reasoning about vocabulary instruction. Dyslexia, 26(2), 173-199. https://doi.org/10.1002/dys.1637

Edwards, C.P., Hamel, E., Leeper Miller, J., \& Ren, L. (2020). Improving reflective practice: A documentation rubric for mentoring preservice and in-service teachers. Journal of Early Childhood Teacher Education, 41(1), 2-17. https://doi.or g/10.1080/10901027.2018.1463321

Eisenhardt, K.M. (1989). Building theories from case study research. Academy of Management Review, 14(4), 532-550. https://doi.org/10.5465/ amr.1989.4308385

Erickson, F. (2011). On noticing teacher noticing. In M.G. Sherin, V.R. Jacobs, \& R.A. Philipp (Eds.), Mathematics teacher noticing: Seeing through teachers' eyes (pp. 17-34). New York, NY: Routledge.

Flynn, E.E., \& Schachter, R.E. (2017). Teaching for tomorrow: An exploratory study of prekindergarten teachers' underlying assumptions about how children learn. Journal of Early Childhood Teacher Education, 38(2), 182-208. https://doi.org/10. 1080/10901027.2017.1280862

Fogarty, J.L., Wang, M.C., \& Creek, R. (1983). A descriptive study of experienced and novice teachers' interactive instructional thoughts and actions. The Journal of Educational Research, 77(1), 22-32. https://doi.org/10.1080/00220671.1983.10 $\underline{885491}$ 
Frankenburg, W.K., Dodds, J., \& Archer, P. (1990). Denver II technical manual. Denver, CO: Denver Developmental Materials.

Fuchs, D., Fuchs, L.S., \& Stecker, P.M. (2010). The "blurring" of special education in a new continuum of general education placements and services. Exceptional Children, 76(3), 301-323. https://doi.org/10.1177/001440291007600304

Gardner-Neblett, N., \& Ebright, B.D. (2021, April). Teachers' perceptions of young children's oral narrative skills: The role of children's race and gender and teachers' race. Paper presented at the virtual biennial meeting of the Society for Research in Child Development.

Gass, S.M., \& Mackey, A. (2000). Stimulated recall methodology in second language research. Mahwah, NJ: Erlbaum.

Gatbonton, E. (2008). ESL teachers' pedagogical knowledge. Language Teaching Research, 12(2), 161-182. https://doi.org/10.1177/1362168807086286

Gaudin, C., \& Chaliès, S. (2015). Video viewing in teacher education and professional development: A literature review. Educational Research Review, 16, 41-67. https://doi.org/10.1016/j.edurev.2015.06.001

Gilbert, W., Turdel, P., \& Haughian, L.P. (1999). Interactive decision-making factors considered by coaches of youth ice hockey during games. Journal of Teaching in Physical Education, 18(3), 290-311. https://doi.org/10.1123/itpe.18.3.290

Gischlar, K.L., \& Vesay, J.P. (2018). Literacy curricula and assessment: A survey of early childhood educators in two states. Reading Improvement, 55(3), 106-117.

Grisham-Brown, J., Hallam, R.A., \& Pretti-Frontczak, K. (2008). Preparing Head Start personnel to use a curriculum-based assessment: An innovative practice in the "age of accountability". Journal of Early Intervention, 30(4), 271-281. https://doi. org/10.1177/1053815108320689

Guba, E.G., \& Lincoln, Y.S. (1989). Fourth generation evaluation. Thousand Oaks, CA: Sage.

Hall, K., Horgan, M., Ridgeway, A., Murphey, R., Cunneen, M., \& Cunningham, D. (2010). Loris Malaguzzi and the Reggio Emilia experience. New York, NY: Bloomsbury.

Horn, I.S. (2015). Teachers learning together: Pedagogical reasoning in mathematics teachers' collaborative conversations. In S.J. Cho (Ed.), Selected regular lectures from the 12th International Congress on Mathematical Education (pp. 333-342). Cham, Switzerland: Springer.

Katz, L.G., Chard, S.C., \& Kogan, Y. (2014). Engaging children's minds: The project approach. Westport, CT: Praeger.

Kincaid, A.P., McConnell, S.R., \& Wackerle-Hollman, A.K. (2020). Assessing early literacy growth in preschoolers using individual growth and developmental indicators. Assessment for Effective Intervention, 45(3), 173-183. https://doi. org/10.1177/1534508418799173

Klute, M., Apthorp, H., Harlacher, J., \& Reale, M. (2017). Formative assessment and elementary school student academic achievement: A review of the evidence (REL 2017-259). Washington, DC: Regional Educational Laboratory Central, National Center for Education Evaluation and Regional Assistance, Institute of Education Sciences, U.S. Department of Education. 
Kostelnik, M.J., Soderman, A.K., Whiren, A.P., \& Rupiper, M.L. (2019). Developmentally appropriate curriculum: Best practices in early childhood education (7th ed.). New York, NY: Pearson.

Lampert, M. (2010). Learning teaching in, from, and for practice: What do we mean? Journal of Teacher Education, 61(1/2), 21-34. https://doi. org/10.1177/0022487109347321

Landry, S.H., Anthony, J.L., Swank, P.R., \& Monseque-Bailey, P. (2009). Effectiveness of comprehensive professional development for teachers of at-risk preschoolers. Journal of Educational Psychology, 101(2), 448-465. https://doi.org/10.1037/ $\underline{\mathrm{a} 0013842}$

Landry, S.H., Smith, K.E., Miller-Loncar, C.L., \& Swank, P.R. (1997). Predicting cognitive-language and social growth curves from early maternal behaviors in children at varying degrees of biological risk. Developmental Psychology, 33(6), 1040-1053. https://doi.org/10.1037/0012-1649.33.6.1040

Lee, J.E. (2014). A study of pre-kindergarten teachers' knowledge about children's mathematical thinking. Australasian Journal of Early Childhood, 39(4), 29-36. https://doi.org/10.1177/183693911403900405

Lembke, E.S., McMaster, K.L., Smith, R.A., Allen, A., Brandes, D., \& Wagner, K. (2018). Professional development for data-based instruction in early writing: Tools, learning, and collaborative support. Teacher Education and Special Education, 41(2), 106-120. https://doi.org/10.1177/0888406417730112

Little, J.W. (2012). Understanding data use practice among teachers: The contribution of micro-process studies. American Journal of Education, 118(2), 143-166. https://doi.org/10.1086/663271

Lonigan, C.J., Allan, N.P., \& Lerner, M.D. (2011). Assessment of preschool early literacy skills: Linking children's educational needs with empirically supported instructional activities. Psychology in the Schools, 48(5), 488-501. https://doi. org/10.1002/pits.20569

Lonigan, C.J., \& Phillips, B.M. (2016). Response to instruction in preschool: Results of two randomized studies with children at significant risk of reading difficulties. Journal of Educational Psychology, 108(1), 114-129. https://doi.org/10.1037/ edu0000054

Marsh, J.A., Bertrand, M., \& Huguet, A. (2015). Using data to alter instructional practice: The mediating role of coaches and professional learning communities. Teachers College Record, 117(4), 1-40.

Marton, F. (1981). Phenomenography-describing conceptions of the world around us. Instructional Science, 10, 177-200. https://doi.org/10.1007/BF00132516

Mason, J. (2011). Noticing: Roots and branches. In M.G. Sherin, V.R. Jacobs, \& R.A. Philipp (Eds.), Mathematics teacher noticing: Seeing through teachers' eyes (pp. 35-50). New York: Routledge.

Maxwell, J.A. (2013). Qualitative research design: An interactive approach (3rd ed.). Thousand Oaks, CA: Sage.

McAlpine, L., Weston, C., Berthiaume, D., \& Fairbank-Roch, G. (2006). How do instructors explain their thinking when planning and teaching? Higher Education, 51, 125-155. https://doi.org/10.1007/s10734-004-6381-x 
Miller-Bains, K.L., Russo, J.M., Williford, A.P., DeCoster, J., \& Cottone, E.A. (2017). Examining the validity of a multidimensional performancebased assessment at kindergarten entry. AERA Open, 3(2). https://doi. org $/ 10.1177 / 2332858417706969$

Mills, M.T., Moore, L.C., Chang, R., Kim, S., \& Frick, B. (2021). Perceptions of Black children's narrative language: A mixed-methods study. Language, Speech, and Hearing Services in Schools, 52(1), 84-99. https://doi. org/10.1044/2020 LSHSS-20-00014

Munby, H. (1982). The place of teachers' beliefs in research on teacher thinking and decision making, and an alternative methodology. Instructional Science, 11, 201225. https://doi.org/10.1007/BF00414280

National Association for the Education of Young Children. (2009). Developmentally appropriate practice in early childhood programs serving children from birth through age 8 [Position statement]. Retrieved from https://www.naeyc.org/sites/ default/files/globally-shared/downloads/PDFs/resources/position-statements/ PSDAP.pdf

National Association for the Education of Young Children. (2020). Professional standards and competencies for early childhood educators [Position statement]. Retrieved from https://www.naeyc.org/sites/default/files/ globally-shared/downloads/PDFs/resources/position-statements/ standards_and_competencies_ps.pdf

National Association for the Education of Young Children \& National Association of Early Childhood Specialists in State Departments of Education. (2003). Early childhood curriculum, assessment, and program evaluation [Position statement]. Retrieved from https://www.naeyc.org/sites/default/files/globally-shared/ downloads/PDFs/resources/position-statements/pscape.pdf

National Early Literacy Panel. (2008). Developing early literacy: Report of the National Early Literacy Panel: Executive summary. Washington, DC: National Institute for Literacy.

Nebraska Department of Education. (2018). Nebraska's Birth to Five Learning and Development Standards. Retrieved from $\underline{\mathrm{https}} / / / \mathrm{cdn}$. education.ne.gov/wpcontent/uploads/2018/06/ELG-PDF.pdf

Nilsson, P. (2009). From lesson plan to new comprehension: Exploring student teachers' pedagogical reasoning in learning about teaching. European Journal of Teacher Education, 32(3), 239-258. https://doi.org/10.1080/026197608025530 $\underline{48}$

Ohio Department of Education. (2019). Ohio's Early Learning and Development Standards: Birth to kindergarten entry: Language and literacy. Retrieved from http://education.ohio.gov/getattachment/Topics/Early-Learning/EarlyLearning-Content-Standards/Birth-Through-Pre K-Learning-and-DevelopmentStand/ELDS-Language-and-Literacy.pdf.aspx

Parker, W.C., \& Gehrke, N.J. (1984, April). A grounded theory study of teachers' decision making. Paper presented at the annual meeting of the American Educational Research Association, New Orleans, LA. 
Piasta, S.B. (2014). Moving to assessment-guided differentiated instruction to support young children's alphabet knowledge. The Reading Teacher, 68(3), 202211. https://doi.org/10.1002/trtr.1316

Quality Compendium. (2020). View state profiles. Retrieved from https:// qualitycompendium.org/view-state-profiles

Schachter, R.E. (2017). Early childhood teachers' pedagogical reasoning about how children learn during language and literacy instruction. International Journal of Early Childhood, 49, 95-111. https://doi.org/10.1007/s13158-017-0179-3

Schachter, R.E., \& Freeman, D. (2015). Using stimulated recall to study teachers and teaching: A brief introduction to the research methodology. In P.O. Lucas, \& R.L. Rodrigues (Eds.), Temas e rumos nas pesquisas em linguística (aplicada): Questões empíricas, éticas e práticas [Themes and directions in research in (applied) linguistics: Empirical, ethical and practical issues] (Vol. 1, pp. 223-243). São Paulo, Brazil: Pontes.

Schachter, R.E., Freeman, D., \& Parakkal, N. (2020). Bifurcated worlds? A systematic review of how visual and language data are combined in the study of teaching. Review of Research in Education, 44(1), 370-402. https://doi. org/10.3102/0091732X20903305

Schachter, R.E., Matthews, A., \& Piasta, S.B. (2021). How do differing stakeholders perceive instances of language and literacy instruction? Journal of Early Childhood Literacy, 21(1), 104-126. https://doi.org/10.1177/1468798418813661 Schachter, R.E., Piasta, S., \& Justice, L. (2020). An Investigation into the curricula (and quality) used by early childhood educators. NHSA Dialog, 23(2), 21-50.

Shavelson, R.J., \& Stern, P. (1981). Research on teachers' pedagogical thoughts, judgments, decisions, and behavior. Review of Educational Research, 51(4), 455498. https://doi.org/10.3102/00346543051004455

Shulman, L. (1987). Knowledge and teaching: Foundations of the new reform. Harvard Educational Review, 57(1), 1-23. https://doi.org/10.17763/ haer.57.1.j463w79r56455411

Simmons, D.C., Coyne, M.D., Hagan-Burke, S., Kwok, O.M., Simmons, L., Johnson, C., ... Crevecoeur, Y.C. (2011). Effects of supplemental reading interventions in authentic contexts: A comparison of kindergarteners' response. Exceptional Children, 77(2), 207-228. https://doi.org/10.1177/001440291107700204

Slavin, R.E., Cheung, A., Holmes, G., Madden, N.A., \& Chamberlain, A. (2013). Effects of a data-driven district reform model on state assessment outcomes. American Educational Research Journal, 50(2), 371-396. https://doi. org/10.3102/0002831212466909

Smith, M.W., Brady, J.P., \& Anastasopoulos, L. (2008). Early Language and Literacy Classroom Observation Pre-K Tool. Baltimore, MD: Paul H. Brookes.

Snow, C.E., \& S.B. Van Hemel (Eds.). (2008). Early childhood assessment: Why, what, and how. Washington, DC: National Academies Press.

Snow, K. (2011). Developing kindergarten readiness and other large-scale assessment systems: Necessary considerations in the assessment of young children. Washington, DC: National Association for the Education of Young Children. 
Souto-Manning, M. (2010). Challenging ethnocentric literary practices: (Re) positioning home literacies in a Head Start classroom. Research in the Teaching of English, 45(2), 150-178.

Squires, J., Twombly, E., Bricker, D., \& Potter, L. (2009). ASQ-3 technical report. Baltimore, MD: Paul H. Brookes.

Stecker, P.M., Lembke, E.S., \& Foegen, A. (2008). Using progress-monitoring data to improve instructional decision making. Preventing School Failure, 52(2), 48-58. https://doi.org/10.3200/PSFL.52.2.48-58

Südkamp, A., Kaiser, J., \& Möller, J. (2012). Accuracy of teachers' judgments of students' academic achievement: A meta-analysis. Journal of Educational Psychology, 104(3), 743-762. https://doi.org/10.1037/a0027627

Teaching Strategies. (n.d.). GOLD. Retrieved from https://teachingstrategies.com/ solutions/assess/gold/

Urhahne, D., \& Wijnia, L. (2021). A review on the accuracy of teacher judgments. Educational Research Review, 32, Article 100374. https://doi.org/10.1016/j. edurev.2020.100374

U.S. Department of Education. (2011). Race to the Top-early learning challenge application for initial funding (CFDA No. 84.412). Washington, DC: Author.

van Es, E.A., \& Sherin, M.G. (2002). Learning to notice: Scaffolding new teachers' interpretations of classroom interactions. Journal of Technology and Teacher Education, 10, 571-596.

van Es, E.A., \& Sherin, M.G. (2006). How different video club designs support teachers in "learning to notice". Journal of Computing in Teacher Education, 22(4), 125-135.

Vanlommel, K., \& Schildkamp, K. (2019). How do teachers make sense of data in the context of high-stakes decision making? American Educational Research Journal, 56(3), 792-821. https://doi.org/10.3102/0002831218803891

Weiland, C., \& Yoshikawa, H. (2013). Impacts of a prekindergarten program on children's mathematics, language, literacy, executive function, and emotional skills. Child Development, 84(6), 2112-2130. https://doi.org/10.1111/cdev.12099

Whitebook, M., McLean, C., Austin, L.J.E., \& Edwards, B. (2018). Early Childhood Workforce Index-2018. Berkeley: Center for the Study of Child Care Employment, University of California, Berkeley.

Whitehurst, G.J., \& Lonigan, C. (2009). Get Ready to Read! Revised. San Antonio, TX: Pearson.

Yeager, D., Bryk, A., Muhich, J., Hausman, H., \& Morales, L. (2013). Practical measurement. Palo Alto, CA: Carnegie Foundation for the Advancement of Teaching.

Yin, R.K. (2014). Case study research: Design and methods. Thousand Oaks, CA: Sage.

Young, V.M., \& Kim, D.H. (2010). Using assessments for instructional improvement: A literature review. Education Policy Analysis Archives, 18(19). https://doi. org/10.14507/epaa.v18n19.2010

Zhang, Z., \& Burry-Stock, J.A. (2003). Classroom assessment practices and teachers' self-perceived assessment skills. Applied Measurement in Education, 16(4), 323342. https://doi.org/10.1207/S1532 4818AME1604_4 
Zweig, J., Irwin, C.W., Kook, J.F., \& Cox, J. (2015). Data collection and use in early childhood education programs: Evidence from the Northeast region (REL 2015084). Washington, DC: Regional Educational Laboratory Northeast \& Islands, National Center for Education Evaluation and Regional Assistance, Institute of Education Sciences, U.S. Department of Education.

\section{Appendix: Planning and Stimulated Recall Interview Protocol}

\section{First observation and interview}

\section{Planning interview}

1. What do you have planned for today? What types of language and literacy activities do you have planned for today?

2. Why did you plan that/those?

\section{Stimulated recall interview}

Prior to beginning the video:

1. How did it go? Is there anything you want to say about the lesson?

During the viewing of the video, if the teacher stops the video:

1. Why is this interesting or out of the ordinary?

2. What was the reason for doing what you did next? OR There are lots of things you could focus on; why did you focus on that? OR Tell me more about why you focused on that. (If necessary provide description about what the teacher did next.)

During the viewing of the video, if the researcher stops the video:

1. At this moment, what where your thoughts? OR At this moment, what were you thinking about?

2. What was the reason for doing what you did next? OR There are lots of things you could focus on; why did you focus on that? OR

Tell me more about why you focused on that. (If necessary, provide description about what the teacher did next.)

3. Why do you think that?

\section{Second observation and interview}

Same as above, with added questions

\section{Planning interview}

3. Did language and literacy assessment data influence your planning?

Stimulated recall interview (regardless of who stops the video)

4. Did assessment data influence what you were thinking about?

5. (If the teacher describes knowing information about a child or children ask) How do you know that? 


\section{Third observation and interview}

Planning interview

1. Did language and literacy assessment data influence your planning?

Simulated recall interview (regardless of who stops the video)

1. Did assessment data influence what you were thinking about?

2. (If the teacher describes knowing information about a child or children ask) How do you know that?

Omit the rest of the questions.

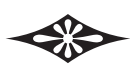

Rachel E. Schachter (corresponding author) is an assistant professor in the Department of Child, Youth and Family Studies at the University of Nebraska-Lincoln, USA; email rschachter2@unl.edu. Her research focuses on understanding early childhood teachers' experiences with curricula, assessment, and professional learning to support meaningful changes in practice and improved outcomes for children.

Shayne B. Piasta is an associate professor in the Department of Teaching and Learning at The Ohio State University, Columbus, USA; email piasta.1@osu.edu. Her research focuses on language and literacy development in preschoolers through elementary school-age children, including how to support this development within the classroom context. 